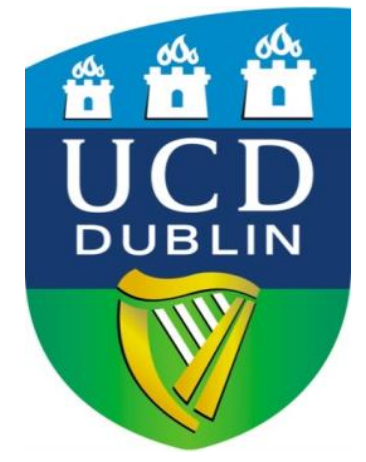

UCD GEARY INSTITUTE FOR PUBLIC POLICY

DISCUSSION PAPER SERIES

\title{
The Troika's variations on a trio: Why the loan programmes worked so differently in Greece, Ireland, and Portugal
}

\author{
Niamh Hardiman \\ School of Politics and International Relations, \\ and Geary Institute for Public Policy, \\ University College Dublin, Ireland \\ Joaquim Filipe Araújo \\ Department of International Relations and Public Administration, \\ University of Minho, Braga, Portugal \\ Muiris MacCarthaigh \\ School of History, Anthropology, Philosophy and Politics, \\ and the George J. Mitchell Institute for Global Peace, Security and Justice, \\ Queen's University Belfast, UK \\ Calliope Spanou \\ Department of Political Science and Public Adminstration, \\ National and Kapodistrian University of Athens, Greece
}

Geary WP2017/11

October 17, 2017

\footnotetext{
UCD Geary Institute Discussion Papers often represent preliminary work and are circulated to encourage discussion. Citation of such a paper should account for its provisional character. A revised version may be available directly from the author.
}

Any opinions expressed here are those of the author(s) and not those of UCD Geary Institute. Research published in this series may include views on policy, but the institute itself takes no institutional policy positions. 
The Troika's variations on a trio: Why the loan programmes worked so differently in Greece, Ireland, and Portugal

Niamh Hardiman

School of Politics and International Relations, and Geary Institute for Public Policy,

University College Dublin, Ireland

Joaquim Filipe Araújo

Department of International Relations and Public Administration,

University of Minho, Braga, Portugal

Muiris MacCarthaigh

School of History, Anthropology, Philosophy and Politics,

and the George J. Mitchell Institute for Global Peace, Security and Justice,

Queen's University Belfast, UK

Calliope Spanou

Department of Political Science and Public Adminstration,

National and Kapodistrian University of Athens, Greece

Corresponding author: Niamh.Hardiman@ucd.ie

Comments most welcome.

This paper is an output of the project on 'The Troika And The Crisis', led by Walter Kickert (Erasmus University, Rotterdam) and Edoardo Ongaro (Open University, $\mathrm{UK})$

October 2017 
1. INTRODUCTION: AIMS AND OBJECTIVES

2. RESEARCH DESIGN 4

3. THE LOAN PROGRAMMES IN CONTEXT

4. ENGAGEMENT WITH LOAN PROGRAMMES: POLITICAL SYSTEM RESPONSES

5. ENGAGEMENT WITH LOAN PROGRAMMES: THE POLITICAL-ADMINISTRATIVE CHALLENGES 17

$\begin{array}{lr}\text { 6. CONCLUSION } & 22\end{array}$

$\begin{array}{lr}\text { ACKNOWLEDGEMENTS } & 24\end{array}$

$\begin{array}{lr}\text { REFERENCES } & 25\end{array}$ 


\begin{abstract}
Portugal and Ireland exited Troika loan programmes; Greece did not. The conventional narrative is that different outcomes are best explained by differences in national competences in implementing programme requirements. This paper argues that three factors distinguish the Greek experience from that of Ireland and Portugal: different economic, political, and institutional starting conditions; the ad hoc nature of the European institutions' approach to crisis resolution; and the very different conditionalities built into each of the loan programmes as a result. Ireland and Portugal show some signs of recovery despite austerity measures, but Greece has been burdened beyond all capacity to recover convincingly.
\end{abstract}

Keywords

Loan programme, Eurozone crisis, Troika, European periphery, conditionality

$J E L$

E02, E62, G01, H30, H77, H87 


\section{Introduction: aims and objectives}

The Eurozone financial crisis posed a major challenge to the EMU principle of 'no bailout' if individual countries found themselves unable to maintain the rules of membership. In 2010 and 2011 Greece, Ireland, and Portugal in turn provided a forced school for EU crisis management. An evolving series of loan programmes was devised to facilitate them: in this manner, the EU provided a 'shelter' against the risk of total financial and fiscal collapse (Thorhallsson 2011). But this was not without significant cost, both immediately and in the trajectory of further development. This paper focuses on the significance of the institutional lenders' engagement with domestic political actors in each of the three countries, and the implications for the manner in which the loan programmes were constructed and implemented in each case.

A conventional perspective would have it that the lenders adopted a largely technocratic approach in the design of the loan programmes, and that variations in performance is largely explicable in terms of both the willingness of national governments to comply and the capacity of their public administration system to implement what was required of them. In this perspective, domestic political capacity to comply with 'austerity' and structural reform is the chief reason for successful exit from loan programmes. Ireland and Portugal are contrasted favourably with Greece's mounting difficulties, which are reflected in the need for three loan programmes with ever-protracted deadlines for eventual exit.

Our approach stresses the often-overlooked complexity of the situation of the three crisis-hit countries, and provides an alternative perspective on the interplay between domestic politics and international loan conditionality.

\section{Research design}

This paper sets out a structured-focused comparison of the three westernEuropean periphery countries that entered loan programmes in 2010 and 2011, run jointly by the 'Troika' of the European Commission (EC), the International Monetary Fund (IMF), and the European Central Bank (ECB). This is conceived of as a most-similar case study research design. The three countries in question all had the same starting position, in that all were extremely vulnerable in the crisis. 
All were subject to loan programmes, and are generally viewed has having been subject to the same 'treatment'. All experienced different outcomes, providing us with variation that needs to be explained. We adopt a comparative structuredfocused research design in the selection of our cases:

The method is 'structured' in that the researcher writes general questions that reflect the research objective and that these questions are asked of each case under study to guide and standardize data collection, thereby making systematic comparison and cumulation of the findings of the cases possible. The method is 'focused' in that it deals only with certain aspects of the historical cases examined (George and Bennett 2005, p.67).

We adopt a causal-process analysis such that we can isolate the variables that are principally responsible for causing the differences in outcome (Brady and Collier 2004: 277).

Firstly, our contention is that the nature of the crisis and its origins in the structure of the international as well as the national political economy in each case was different, so interventions were always going to work differently in each case. Secondly, the parties to the Troika were not of the same mind on all aspects of the conditionalities entailed in the loan programmes. Thirdly, lenders' expectations and requirements corresponded to different degrees with the priorities emerging within national political debate in each case. Consequently, we should not be surprised that the outcomes of each of the loan programmes were different.

The first step in our argument is that domestic conditions acted as mediating variables. The initial economic conditions mattered, and the nature of the political system mattered. However, administrative 'ownership' of the programmes did not depend only on domestic conditions, but also on what was required in each case. We therefore further argue that the 'treatment' was itself also quite different, in that the conditionality brought to bear on each country varied, and that this had a significant bearing on each country's capacity to implement its loan programme in full. An important contribution of this paper is to show that the trio of countries subject to Troika supervision were not subject 
to 'the same' treatment. Variation in the requirements of each loan programme was an important source of variation in the outcome of the three countries' experiences with their respective loan programmes.

Section 3 sets the three countries' pathways to crisis in the wider European frame, outlining the evolution of European priorities that shaped the Troika's requirements. Competing priorities within the Troika itself also had an important bearing on the way they implemented the loan programmes from the outset. The next two sections examine the domestic conditions that mediated Troika conditionality. Section 4 focuses on the configuration of the party systems and the role of organized economic interests that shaped the terms of national engagement with the Troika. Section 5 looks at variation in the way the administrative systems of each country responded to and dealt with what the Troika required of them.

Finally, we draw out some implications. We note that domestic politics and administrative systems played an important mediating role in explaining variation in the way these three countries engaged with the Troika. But variations in what the loan programmes required played a big part in explaining variations in the outcomes. Although all three political systems experienced intense pressures arising from their engagement with the Troika, its role in Greece stands out as different in kind from its involvement in Portugal and Ireland.

\section{The loan programmes in context}

'Crisis-hit European countries wasted their money on "drinks and women"' (Khan and McClean 2017). This unfortunate remark in March 2017 from Jeroen Dijsselbloem, head of the Eurozone's finance ministers, encapsulates a persistent myth that has surprising endurance and that fuels northern European resentment against the supposedly profligate south (or periphery, to include Ireland). But the origins of the Eurozone crisis are a good deal more complex.

The fiscal crisis that emerged in 2008-2010 was embedded in a growing set of macroeconomic imbalances that had been enabled by the design of the Eurozone itself (Regan 2017, Johnston and Regan 2015). The Single Market had facilitated 
a huge increase in international bank lending since the 1990s, particularly after 1999. The faster-growing periphery faced negative real interest rates relative to the then-sluggish savings-rich core countries, inducing perverse incentives to borrow (Véron 2016). The domestic consequences of loose money differed, depending on the domestic conditions of their absorption. Private sector consumption and investment in non-productive construction projects were common experiences, but in Ireland and Spain this created extraordinary housing bubbles. Public sector borrowing accrued most rapidly in Greece. In all the periphery countries (Greece, Ireland, Portugal, and Spain), the net external debt of the periphery countries grew rapidly as a result. The 'sudden stop' of the international credit crisis left the highly over-exposed banks of the 'core' economies with huge liabilities (Baldwin and Giavazzi 2015, Copelovitch, Frieden, and Walter 2016, Merler and Pisani-Ferry 2012, Jones 2015). The sudden stop in turn precipitated the fiscal crises that became the first focus of the Eurozone crisis (Dellepiane-Avellaneda et al. forthcoming).

Both Ireland and Portugal ran fiscal surpluses right up to the crisis (as indeed did Spain): the bulk of credit expansion was in the private sector. Greek private sector indebtedness had already increased, but public sector balance sheets had expanded even more rapidly. This was not a new phenomenon in Greece: its eligibility for the Euro in 1999 had been approved despite known weaknesses in public accounting practices. The sharp drop in the public finances was due in all three countries to the downturn in the 'real' economy associated with job losses and falling tax returns, but it was amplified by the transmission of risk and liability from the banking sector to the sovereign (Mody and Sandri 2012, Jones 2015). It was, in essence, the EU's inability to break the bank-sovereign 'doom loop', and the controversies over burden-sharing in the European financial sector that followed, that pushed first Ireland and then Portugal into crisis.

Meanwhile Greece experienced difficulties re-financing its public sector debt. It was the European institutions' inability to stall the loss of market confidence, through its hesitant and limited extension of cover, that caused Greece's crisis to spiral out of control. It was not until the later confidence-building intervention of the ECB from 2012 onward, in the form of its bond-buying Outright Monetary 
Transaction (OMT), and its injection of increased liquidity in the form of Quantitative Easing (QE), that stability was restored (De Grauwe and Ji 2015). The design failures of the Eurozone left it unprepared to manage crisis, and made ad hoc country-by-country solutions inevitable (De Grauwe 2015, Schmidt 2010). Greece was the first, the most demanding, and the most intractable test for EMU.

Disagreement between the members of the Troika over the terms on which assistance would be afforded was in evidence from the outset, and shaped the terms on which the loan programmes were implemented in each of the three countries under review here (IMF Independent Evaluation Office 2016). The IMF was invited to participate to bolster the European Commission's inexperience in managing loan programmes; the ECB was intended to be an observer rather than a policy-setter. The IMF's role in stabilising the European financial sector has been recognized (Véron 2016). But problems arose within the Troika in two important areas. Firstly, the IMF's views did not prevail on the matter of restructuring the Greek debt, the imposition of high interest rates on the loan programmes, and the terms of bank recapitalisation. The ECB (bolstered by the US Treasury Secretary and by the European finance industry) resisted imposing losses on senior bank bondholders, and required that national public finances assume the burden of full restitution, the better to protect the fragile balances of banks in Germany and France (Kalaitzake 2017, Kyriakidis 2016, Porzecanski 2013). And even though a later renegotiation yielded some relief on the costs of bank recapitalisation for Ireland, the damaging perception persisted that this had been a punishing deal (Whelan 2012). The IMF later acknowledged that its acquiescence on these issues had been a mistake and that it had sacrificed too much of its independence to the ECB and the EC (Donovan 2016: 28, IMF Independent Evaluation Office 2016). Secondly, the IMF's own assessment of the effects of Eurozone fiscal retrenchment pointed out that the cross-border spillovers were generating larger than anticipated multiplier effects, worsening the experience of austerity (IMF 2012). Yet the EU not only possessed no fiscal transfer capacity to alleviate this, it had very little ability to transcend the intergovernmental decision-making process that was bound to result in 
suboptimal outcomes from the perspective of the Eurozone as a whole (Jones, Kelemen, and Meunier 2016).

Against this backdrop, the conditions under which first Greece then Ireland and Portugal were obliged to enter into loan programmes were different, and the starting conditions contribute some insight into how the politics of implementation worked out in each case.

In all three countries, the inrush of cheap capital after 1999 had largely been absorbed in unproductive investments in increased consumption (especially construction in Ireland, private consumption in Portugal and Greece, and public spending in Greece). Deteriorating real effective exchange rates resulted in loss of competitiveness as measured by unit labour costs, and soaring balance of payments deficits. Neither the financial markets nor the EU Commission had expressed concern over these imbalances (Hardouvelis and Gkionis 2016: 5). The core had little incentive to refrain from reckless lending (the corollary of extensive borrowing). Fiscal policy was not well disciplined by the Stability and Growth Pact, and periphery countries' ability to control the consequent inflationary surges and consumption booms was very limited (Hallerberg and Bridwell 2008).

In 2009, the incoming PASOK government revealed that Greece's general government deficit was in fact $15.2 \%$ of GDP, and the sovereign debt $115 \%$, much higher than previously officially reported. In early 2010, markets withdrew their confidence from Greek bonds. Despite successive rounds of drastic measures to cut deficits, Greece became the focus of intense market pressure, testing the resistance of the Euro itself. The European authorities' management of the crisis was characterized by 'kicking the can down the road', or more formally, by ad hoc solutions devoted to expanding European powers just enough to meet the immediate challenge, yet deepening integration and interdependencies by default, and creating the conditions in which more extensive solutions would be required in the future. This habit of 'failing forward' recurred, from the European Financial Stability Fund to the European Stability Mechanism, to the Fiscal Pact, to the as-yet incomplete banking union (Jones, Kelemen, and Meunier 2016). New fixes had to be devised in response to 
successive crises in Greece, Ireland, Portugal - and Greece again. Yet the fundamental requirements for sustained stabilisation such as a fiscal transfer union, public debt mutualisation, and pooled bank recapitalisation, remained politically impossible to reach.

The loan programmes for Greece (in 2010, again in 2012, and again in 2015), in Ireland (in 2010) and in Portugal (in 2011) involved ambitious targets for deficit reduction (Kickert and Randma-Liiv 2015). The total loan to Ireland came to $€ 85 \mathrm{bn}$. Ireland was expected to reduce its fiscal deficit of $11.7 \%$ (net of the costs of bank recapitalisation) to 7\% in 2012 and to below 3\% by 2014 . The terms of Portugal's loan programme, totalling €78bn or $44.3 \%$ of GDP, required it to cut its deficit from $11 \%$ in 2010, to $4.5 \%$ in 2012, and to a little over $2 \%$ by 2013.

In Greece's case though, the first loan programme, scheduled to run from May 2010 to 2013 (which amounted to €110bn, of which €73bn was disbursed), was very large, and amounted to some 18\% of GDP. But by 2012 it was evident that the initial emergency provisions were insufficient to meet Greece's needs. The second programme in March 2012 projected further significant fiscal retrenchment. This was to yield a primary budget deficit of 1\% in 2012 and a primary surplus of $4.5 \%$ in 2014 , and this surplus was to be sustained into the future until the debt-to-GDP ratio was reduced sufficiently. Given the clear unsustainability of the Greek debt, restructuring (PSI) was undertaken that involved a nominal haircut of $53.5 \%$. Privatization to the value of $€ 50 \mathrm{bn}$ was to be undertaken over a longer horizon, well beyond 2015. The banks were to be recapitalized and then added to the pool of assets to be privatized. The second loan programme was worth $€ 134 \mathrm{bn}$, but given the extreme difficulties with implementing it, over $€ 130 \mathrm{bn}$ was not disbursed. The debt load was so great that not only was Greece still debarred from market financing, it was required to accept a third programme in August 2015, to the value of $€ 86 \mathrm{bn}$. The targets remain similar to those of the second programme. The principal purpose of the programmes was to keep existing loans turning over rather than to fund growthpromoting investment. It is evident therefore that the scale of the challenge - and the realistic prospect of programme delivery and debt sustainability - was very different in the case of Greece compared with the two others. 
All three countries were also required to accept 'structural adjustment' conditionalities. Here again, the scale and complexity of what was required was very different: the social and labour market conditionalities have been described as being of 'unprecedented intrusiveness' in Portugal and Greece (Theodoropoulou 2015, p.29), while Ireland's more liberal labour market was not specifically targeted.

The measures typically involved liberalizing labour markets, deregulating services, and privatization to improve efficiencies. Measures were not closely tailored to the circumstances of individual countries. They were therefore often controversial and perceived as motivated more by the ideological preferences of the lenders than by realistic expectations of growth promotion. The conditions were relatively light in Ireland, with its already quite flexible labour market, plans for banking sector reform, and national commitment to improving work activation measures. Some of the 270 measures were contested though, most strikingly liberalisation of the legal profession, successfully resisted by its wellorganized lobbyists; and removal of wage floors, successfully reinstated after the 2011 change of government. Conditionality in Portugal totalled 223 measures but ran counter to a wider range of established policy practices. Apart from bank restructuring, these included labour and product market reforms, competition in protected sectors, and reform of the judicial system. Firm-level competitiveness was to be improved chiefly by reducing both direct and indirect labour costs. Liberalization of the labour market loomed particularly large in the Troika's priorities: the Labour Code was extensively revised and job security reduced.

The conditionalities imposed upon Greece in each of the programmes were far more extensive. They greatly extended the scope of what the primary purpose of the loan programme was originally intended to achieve, and did so in a manner that lacked focus, prioritisation, or coordination. But while Greek policy actors could recognize deficiencies in their own system, the ambition to restructure great parts of the Greek state under the aegis of a fiscal and financial assistance programme proved decidedly problematic. Even in instances where better institutional practices would be more efficient or more effective, the number, scale, and phasing were problematic; the evidence base for prioritizing some 
over others was contested; and the appropriateness of institutional reform being tied to the disbursement of loans was deeply resented. This was the main source of many of the legitimation and compliance problems that beset the Greek programmes.

The fiscal targets were broadly met in Ireland, were more problematic in Portugal, and involved constant slippage in Greece. A good part of the problem in Portugal and Greece stemmed from the fact that the projections for recovery were - as was later acknowledged - far too optimistic in the context of international recession, the absence of any coherent strategy for growth, and the lack of any resources for investment (Sapir et al. 2014). Ireland's growth prospects were better because it had long prioritized export-led growth, and because it was strongly connected to the much more vibrant US and UK markets (Brazys and Regan 2017, Regan and Brazys 2017). But Portugal and Greece had relatively stronger reliance on growth based on domestic demand, which was now severely depressed. Export performance were not primarily driven by issues of cost competitiveness and would not be improved simply through austerity (Böwer, Michoi, and Ungerer 2014, Marques 2015).

Nonetheless, all three countries achieved outstanding performance on the main commitments of their respective programmes. On the key criterion of fiscal consolidation, between 2009 and 2012 alone (based on OECD data), Greece achieved an 11-percentage-point improvement in its primary fiscal balance, Ireland 8 points, and Portugal 7. All three also had excellent scores on the implementation record of the programme conditionalities: over $90 \%$ in Ireland, $80 \%$ in Portugal, and almost $80 \%$ in total in Greece, notwithstanding the enormous political challenges it faced (Terzi 2015: Figs. 2 and 3). And all three were the leaders in the OECD scoreboard of 'overall reform responsiveness' between 2007 and 2014 (OECD 2015: Fig.4.2).

But all of this came at a terrible cost in their respective societies. EMU itself imposed tight constraints. Periphery countries could not engage in countercyclical fiscal stimulus; internal devaluation proved destabilising not only to the financial system but politically too; and debt levels could not fall under conditions of low growth and zero inflation. Greece was the country most 
severely caught in the debt trap that necessarily follows, but Portugal was also vulnerable, and was also troubled by unresolved weaknesses in the banking system. Ireland's apparent escape risked being undermined by Brexit and by uncertainty over possible change to US corporate tax policy (Ó Ceallaigh 2017, Smith et al. 2017).

The social cost of the years of austerity was borne by the unemployed, by those exposed to the hardships entailed by worsening social services, and by the rising numbers of those experiencing poverty. Youth unemployment re-emerged as little short of a social disaster: Portugal and Greece, along with Spain, had by far the largest proportion of NEETs in the EU, that is, young people not in employment, education, or training, with about half of all youth out of work in Greece in 2015, and one-third in Portugal (and about one-fifth in Ireland) - a lost generation (Mascherini and Ledermaier 2016). Labour market deregulation in Greece and Portugal, together with the pressure of extreme unemployment, further depressed salaries and favoured abusive practices. In Greece, the poverty line was reset downwards, yet recorded poverty grew deeper and more pervasive (Matsaganis and Leventi 2014, Giannitsis and Zografakis 2015: 133). On an aggregate index of 'social justice' including access to health care, education, the labour market, poverty prevention, and social cohesion, Ireland was in the middle third at $18^{\text {th }}$ place in 2015; Portugal ranked among the bottom third, at 22nd place, in 2015; while Greece was the worst-performing EU country (Schraad-Tischler 2016).

The loan programmes visited considerable social hardship upon the populations of the three countries. The political resources available to manage, explain, and implement the programmes in each country varied considerably. And in turn, the experience of programme implementation created new problems of contestation, of protest, even of resistance for their governments. The challenges were on a different scale of magnitude in Greece - and the political resources there were already more problematic than in the other two countries. The following two sections explore the political intermediation of the loan programmes, and the administrative politics of programme implementation. 


\section{Engagement with loan programmes: political system responses}

The pressure of compliance with loan programmes put the role of the Parliament and of social dialogue institutions to a severe test. Party systems were placed under immense pressure as they were obliged to bend to priorities that were set externally. Where institutions of wage bargaining and social dialogue were marginalized, high levels of social mobilisation resulted in strikes and at times street protest. 'Bridging' across divisions in party politics was easier in Ireland than in Portugal, but virtually impossible in Greece. However, conflicts also emerged in Portugal and Ireland, testifying to the political strain on all governments that had to implement loan programmes.

Greece featured a strong executive in a highly polarized political system, which had long been characterized by deep clientelist relations extending throughout state institutions and civil society alike (Featherstone 2011). Democratic stabilisation since the 1970s had been based on incorporating workers into the political system through strong patronage networks operated by the socialist PASOK and conservative New Democracy alike, though the radical left had remained strongly anti-system. Spending cuts now disrupted governments' capacity to sustain consent. The pressure of conditionality, and the urgency of the timeframe involved, led to the further marginalisation of democratic and constitutional concerns. The time available for real debate that could help build national ownership of the reforms was squeezed out, and government relied increasingly on non-parliamentary legislative mechanisms (Auel, Eisele, and Kinski 2016). The compliance requirements set by the Eurogroup did not appear to be sensitive to the domestic complexities that successive governments had to contend with. Ongoing austerity generated more anger and more social protest in Greece than in the other two countries. It was all but impossible for any government assuming responsibility for meeting programme targets to do so in these circumstances.

In Portugal, alternation in power of centre-right Social Democrats (PSD) and centre-left Socialists since democratisation in the 1970s had, in the main, contained the challenge from the extreme left. The party system was less deeply dependent on clientelism to sustain support, so spending cuts were less 
systemically damaging (Afonso, Zartaloudis, and Papadopoulos 2014). The loan programme came about because the centre-right Social Democrats refused the recovery plan (PEC IV) proposed by the minority centre-left Socialist (PS) government, which had been approved by the European Commission. The PSD leader Pedro Passos Coelho pressured prime minister José Sócrates to request financial aid to avert an impending insolvency crisis. The PSD secured a majority in the early election of mid-2011 which enabled them to implement the loan programme (Banco de Portugal 2016). The PS's electoral defeat and the breakdown of social dialogue started a new cycle of labour conflict. The rival union confederations (UGT and CGTP) resorted to street protests of a sort that had not been seen for twenty years.

Ireland is different again. The political system featured two large centre-right parties and a weak left-right division. The dominant Fianna Fáil government's own national recovery plan informed the content of the loan programme in November 2010. The new government that took power in early 2011, a majority coalition of centre-right Fine Gael and centre-left Labour Party, pushed for some changes in priorities but largely adopted the programme as it was. Street protests were less pervasive than either of the other two countries. The Irish government re-opened social dialogue with the public sector unions during 2010 on pay cuts consistent with the 'recovery' plan (Regan 2013).

The politics of political 'ownership' was most contentious in Greece and least so, though still problematic, in Ireland. But the wrenching experience of crisis in all three countries has had a further set of consequences that are all but invisible to the official commentators on programme compliance, and that is the shattering effect it has had on their political systems. Austerity cost incumbent parties dearly, and changed the configuration of party political competition. Unlike the European 'core', where austerity on top of three decades of globalisation and deindustrialisation gave rise to populism of the nationalist right, the protests in the periphery largely benefited leftists. It created greater fragmentation of opinion and growing challenges to stable government formation (Hardiman et al. 2017). 
The shifts were most extreme in Greece. The newly elected centre-left PASOK government in 2009 was the only party of the five main players in parliament to accept the inevitability of the loan programme. It was accused of 'bringing the IMF into the country', even of 'treachery' (Papaconstantinou 2016). Under the stresses of dealing with the first loan programme, the party system imploded, and PASOK was all but obliterated in the 'earthquake' election of May 2012. Eventually a new coalition comprising the centre-right New Democracy party, PASOK, and Democratic Left was formed, but this encountered extreme difficulty implementing the second programme after 2012. The main beneficiary of the delegitimation of the two great pillars of post-Junta democratic politics was Syriza, previously a tiny party of the radical left with a communist background. Playing to strong anti-Memorandum emotion, it secured over one-third of the popular vote in January 2015, and formed an 'anti-austerity' coalition government with the small right-wing nationalist-populist party ANEL. Creditors may have hoped that a leftist government would be more efficient in promoting difficult reforms because it would be in a position to control protest. But this only came about after confrontation between the new Syriza government and the Eurozone ministers in spring of 2015 that cost the government a great deal of political capital. Even tougher fiscal targets were then embedded in the $3^{\text {rd }}$ adjustment programme. By now, all parties in Greece were committed to accepting the terms of the loan programmes. Protest mobilisation, lacking any party outlet, resumed during 2016 and 2017.

In Portugal, alternation between blocs of centre-right and centre-left in the course of managing the crisis was fundamentally challenged, bringing the far left into play for the first time in 2015 in support of a minority centre-left government (Coelho et al. 2016). In Ireland too, management of crisis proved almost as much of an electoral liability as perceived responsibility for causing the crisis. Here also the three longest-standing parties suffered heavily. As recently as 2007 the three main parties had taken about $90 \%$ of the vote share; in 2016 this was down to 57\%. As in Portugal (and indeed Spain), the fragmentation of the party system generated new instability in government formation (Little 2011, 2016, Hardiman et al. 2017). Political system instability is one of the major not-so-hidden legacies of the crisis. 


\section{Engagement with loan programmes: the political-administrative}

\section{challenges}

Relations between the Troika and key policy actors were most problematic in Greece, less so in Portugal, least so yet still difficult in Ireland.

The Troika's Greek experience was the most fraught by quite some measure, due not only to the nature of the pre-crisis political economy, but also to the political challenges involved in establishing a common frame of reference in domestic politics. A broad-based domestic agreement on the unavoidability of working within the loan programme was only achieved after five immensely difficult years, many slippages, and much ground lost. Along the way Greece experienced two episodes of stand-off between the elected Greek politicians and the European decision-makers: the creation of an EU-approved technocratic government between November 2011 and mid-2012, and the failure of the challenge brought by the newly-elected Syriza government in the first half of 2015. No real convergence between the perspectives of national and international actors was ever fully secured.

As the loan programme evolved, the Troika enlarged its contacts beyond the core group of Prime Minster and Finance Minister to include the various ministries involved in detailed policy implementation. For most of the ministers, their first encounter with the Troika came on the occasion of the first review of the programme in the summer of 2010. Though some ministers realized what was needed, meetings were not easy either in substance or in format: 'To many ministers, the meetings tested the limits of the right of a democratically elected government to run its own affairs [...]. The ministers had difficulty adapting to this kind of monitoring. Some were open and forthcoming, others formal and distant', doing only 'as much as is strictly necessary' (Papaconstantinou 2016: 158, 155). The Minister for Finance under the first Memorandum was scapegoated within his own party, and the parliamentary group itself turned against him in mid-2011. Consultation with civil society stakeholders became virtually impossible, diminishing the chances of successful policy implementation. 
The Greek state's capacities were rolled back more extensively than in either of the other two countries through enormous personnel losses, extensive changes in the labour market, and widespread deregulation, liberalisation, and privatization of utilities. Since quick implementation was prioritized, many state officials were sceptical that any real empirical evidence existed that the measures they were asked to execute were indeed serious impediments to the functioning of the Greek economy. Greek politicians and public administration personnel experienced pervasive involvement by Troika staff, who were embedded throughout the system to work on details of state reform in an intensively micro-managed approach. Yet the depletion of state capacity made the short timetables and the rapid accumulation of reform tasks ever more difficult to respond to and see through.

This resulted in a very uneven degree of cooperation on the part of government and administrative system. A number of the initial structural reforms, even when regarded as valuable, proved politically very difficult to implement in an ideologically unprepared yet highly mobilized society. Nonetheless, most of the required measures were observed in the first programme. Even more difficult measures were mandated under the second programme. Despite encouraging signs in 2014, 'reform fatigue' disrupted the fragile recovery process driven by Samaras, the New Democracy Prime Minister. Syriza's win in 2015 derailed this phase of reform effort. Syriza had long vilified the Troika as enemies of the state and enemies of the people. Cooperation with the representatives of the international organisations now all but ceased, and there were protracted delays in the review process. Syriza's July 2015 referendum was ostensibly a mandate for a 'no to any new programme'. But all fiscal reserves were exhausted. As the risk of a possible forced exit from the Euro flared up anew, the new government faced exactly the same dilemmas as its predecessors. The even tougher terms of the third MoU were undoubtedly motivated at least in part by the intense frustration evinced by the Troika over what they perceived as wilful stalling. However, it should be noted that all the required measures were indeed adopted eventually. Fiscal structural adjustment amounted to around 16\% GDP between 
2010-15, and 2016 and 2017 saw further grinding compliance taking place (IMF 2017).

In its fifth review of the second programme, the IMF commended Greek governments for achieving 'the strongest cyclically-adjusted fiscal position within the euro area in just four years' (IMF 2014: 22-23). But not only did the IMF harbour deep scepticism over debt sustainability on the terms built into the programmes, it also came to believe that the EC-ECB insistence on continued austerity with a view to maintaining a persistent fiscal surplus was both economically damaging and politically unsustainable (IMF Independent Evaluation Office 2016). However, none of this was reflected in the programme reviews.

The political difficulties involved in programme implementation are reflected in delays over finalising the programme reviews, which become more frequent and more protracted with each programme. The first programme completed all reviews despite difficulties and minor delays. Only five out of sixteen evaluations of the second programme signed with the IMF were completed in four years. The fifth review of the second programme was never completed, as it fell foul of the mounting social and political discontent that brought Syriza to power. Review of the implementation of the third programme by the Syriza-led government showed further lengthy delays: one quarterly review was completed with a delay of ten months, and the second was completed in summer 2017, over a year later than planned.

Portugal's experience was closer to Ireland's than to Greece's in that the loan programme was consistent with priorities that were already plausible to - and adopted by - the political leadership. Before the eruption of the 2008 financial crisis, the incumbent majority Socialist government had already initiated austerity policies and reforms aimed at fiscal consolidation. But the party politics behind was more conflictual than in Ireland. The new financial downturn 'caught Portugal in the middle of an adjustment process' that had been 'slow and partial' (Torres 2009, 67), adding new austerity to the old. The austerity measures required by the loan programme were contested: left parties still favoured counter-cyclical stimulus as the better route to recovery. The minority Socialist 
government in power between September 2009 and June 2011, under PM José Sócrates, found it increasingly difficult to manage the adjustments required to distance Portugal's experience from Greece's in the eyes of the financial markets. The new centre-right government under Passos Coelho had a stronger hand to impose tough programme-related measures.

Unlike the Greek experience, reform-minded centre-right ministers quickly accepted the merits of state-reforming conditionality embedded in the loan programme, particularly in areas such as streamlining the social security system, and education and training policy. While pressure from the Troika caused the Greek party system to buckle and cabinet solidarity within government to crumble, it actually strengthened the hand of the executive in Portugal on issues on which it was in agreement with the lenders. The loan programme offered an opportunity to implement policies that could not be openly stated or submitted frankly to the voters. The prime minister acknowledged the integration of the Memorandum into the government programme, and even said that he would 'go beyond the goals of the agreement' in imposing austerity (Público 2011). Finance Minister Vitor Gaspar wanted 'to implement the agenda of structural transformation as fast as we possibly can'. The Prime Minster created a small task force of about 15 persons, the ESAME, or Memorandum Tracking Structure, which was responsible for following up on program implementation, particularly at ministerial level. Several Memorandum measures required two or more ministries' involvement, and cooperation between them was important for success. Government ministers could push reforms they wanted; they 'often required the international lenders to insert some items in the document to get reforms easier' in order to circumvent opposition (Moury and Freire 2013, 19). Disagreement with the Troika about priorities or implementation engendered dialogue and negotiation rather than the withdrawal of compliance frequently noted in Greece (Moury and Standring 2017).

Overall, this meant that there was wide-ranging cooperation from the Portuguese authorities with the Troika, despite left-wing criticism and occasional veto-player activity from the Constitutional Court on measures such as social security cuts. But Portugal was prey to 'reform fatigue', just like Greece. 
In 2013 the Troika reported that the social and political consensus that had buttressed programme implementation had weakened significantly. The Finance Minister resigned in July 2013, acknowledging that failure to meet budget targets 'undermined' confidence in his role at the helm of the reforms. Portugal achieved a 'clean exit' from the loan programme in May 2014 without having to accept a provisional credit line. But while the economy slowly resumed growth, it still had a debt of about $130 \%$ of GDP and its banks were regarded as still problematic. Fiscal stability and growth prospects remained problematic in the context of stagnation in the wider European economy.

The Irish administrative system's experience of programme implementation was less conflictual than that of Greece, and more like that of Portugal. The loan programme required fiscal retrenchment on a scale and to a timetable that fitted the ideational framework shared by the dominant policy community in Ireland (Hardiman 2014). This facilitated convergence among the main parties on the terms that would be required by the Troika.

The government's own National Recovery Plan of November 2010 became the substance of the Memorandum with the Troika, and the incoming coalition government in March 2011 took over the main obligations of its predecessor and committed itself to meeting all the targets. Some issues proved contentious between the new coalition partners, particularly in areas of social protection, wage floors, and bargaining rights, where the Labour Party pressed hard for the interests of welfare recipients, public sector employees, the low paid (Regan 2013). Nonetheless, the cross-party agreement on the principle of the loan programme in the 'national interest' is striking.

The post-2011 government had a large majority, and used it to drive through the terms of the agreement. It established an inner cabinet committee, the Economic Management Council consisting of the Taoiseach or Prime Minister, the two key economic ministers, and the Minister for Social Protection, to coordinate priorities and deliver on the programme. A well-placed IMF commentator commented on the high degree of program ownership by the authorities throughout'(Donovan 2016: 19). 
That is not to say that relations with the Troika were altogether smooth. As in the other countries, the need to subject national policy to the Troika's approval was experienced as humiliating, and the pressure to meet the quarterly targets for each programme review was gruelling. Many detailed items were held by the senior administrators to be inappropriate. But as in Portugal, political and administrative actors pushed for negotiations with the Troika on contentious issues rather than resorting to nominal compliance and substantive avoidance. This frequently resulted in Troika consent to changes in scale, phasing, or sometimes content of reform measures, as long as the measures were consistent with fiscal targets. Senior administrators in the Department of Finance note that the IMF displayed more flexibility in striking deals than the EC or ECB representatives. Ireland eventually signed off on all 270 programme objectives. But they were not necessarily the same 270 , or delivered on the same time-scale as envisaged at the outset (interviews with senior Department of Finance officials, 19 July 2017).

Relations with other interlocutors went less well. The IMF was committed from the outset to 'public outreach' and dialogue with opposition parties and major 'stakeholders' (Donovan 2016: 20). But trade unions and civil society organisations were distinctly unimpressed by their meetings with the Troika. They held that the Troika members were simply going through the motions and had no real interest in any of the issues about poverty, unemployment, or hardship that were put to them. Indeed, the Irish Congress of Trade Unions withdrew from the meetings and refused to accord the Troika any further legitimacy (interview with senior trade union official, 28 March 2017).

\section{Conclusion}

Greece, Ireland, and Portugal engaged actively and, within the main performance parameters, highly successfully with the Troika. But all suffered severe wealth destruction, disruption of livelihoods, and the sacrifice of a generation of young people. The long-term impact on the quality of public services and the implications for those dependent on them would continue to play out for quite some time. In all three countries, the demands of compliance exacted political costs in the form of the destabilisation of party systems. 
In each case, entering a loan programme was perceived as a better option than having to make a sudden crunching adjustment to the loss of market confidence in their sovereign debt. But the terms on which austerity measures were imposed, and the incapacity of the European authorities to see beyond narrow technocratic targets, generated much resentment.

Growth and economic recovery came about most quickly in Ireland, despite and not because of austerity: its longstanding strategy of attracting inward foreign direct investment is the main source of new growth (Brazys and Regan 2017). Portugal saw some hope of new growth, but with much to make up for in lost output over the preceding years (Wise 2017). Greece, though, could see little prospect of relief from debt and austerity. Economic activity stalled and the social fabric was shredded. Greece suffered the biggest drop in legitimacy not only of the European institutions but of the national political system too.

An important theme in our analysis has been to show that Greece was faced with onerous conditionalities at the very moment when its political system and social structure was least able to deal with them. The basic problem of debt unsustainability meant that the fresh loans were mostly absorbed in servicing older loans. Greek governments had to fight 'an uphill implementation battle', and the Troika itself had 'conceded that the whole strategy needed a re-think as early as the beginning of 2011' (Mouzakis 2017). Indeed, new academic research in August 2017 endorsed the view that growth-promoting fiscal stimulus need not carry long-term costs even for countries with high debts (Auerbach and Gorodnichenko 2017). This caused Harvard scholar Jason Furman, former chair of Barack Obama's Council of Economic Advisers, to conlude that: 'We have been giving catastrophically bad advice to countries with high debt to GDP ratios' (Fleming 2017).

Greece had been allowed to bear the brunt of the European adjustment project. But the exit of Portugal and Ireland from loan programmes did not make the EU's piecemeal approach to crisis resolution any less problematic. Greece, despite its considerable domestic efforts, continued to bear disproportionately heavy costs, with little prospect of relief in view. 


\section{Acknowledgements}

This paper was presented at a workshop in The Hague, the Netherlands, 15-16 June 2017. Thanks to all the participants in that workshop for constructive feedback, and particularly to Walter Kickert and Edoardo Ungaro. 


\section{References}

Afonso, Alexandre, Sotirios Zartaloudis, and Yannis Papadopoulos. 2014. "How party linkages shape austerity politics: clientelism and fiscal adjustment in Greece and Portugal during the eurozone crisis." Journal of European Public Policy $22(3): 315-334$.

Auel, Katrin, Olga Eisele, and Lucy Kinski. 2016. "From constraining to catalysing dissensus? The impact of political contestation on parliamentary communication in EU affairs." Comparative European Politics 14 (2):154176.

Auerbach, Alan J., and Yuriy Gorodnichenko. 2017. "Fiscal stimulus and fiscal sustainability." Berkeley, CA: Berkeley University, https://www.kansascityfed.org/ /media/files/publicat/sympos/2017/auerbachgorodnichenko-paper.pdf?la=en

Baldwin, Richard, and Francesco Giavazzi. 2015. "Towards a consensus on the causes of the EZ crisis." Vox, Vox CEPR e-book. http://www.voxeu.org/article/towards-consensus-causes-ez-crisis

Banco de Portugal. 2016. "Entrevista do Governador do Banco de Portugal, Carlos da Silva Costa, ao Expresso." Lisbon: Banco de Portugal, https://www.bportugal.pt/intervencoes/entrevista-do-governador-do-banco-deportugal-carlos-da-silva-costa-ao-expresso

Böwer, Uwe, Vasiliki Michoi, and Christoph Ungerer. 2014. "The Puzzle of the Missing Greek Exports." Brussels: European Commission, European Economy Economic Papers 518. http://ec.europa.eu/economy_finance/publications/economic_paper/2014/pdf/e cp518_en.pdf

Brady, Henry E., and David Collier, eds. 2004. Rethinking Social Inquiry: Diverse Tools, Shared Standards. Lanham, MD: Rowman \& Littlefield.

Brazys, Samuel, and Aidan Regan. 2017. "The Politics of Capitalist Diversity in Europe: Explaining Ireland's Divergent Recovery from Crisis." Perspectives on Politics 15 (2):411-427.

Coelho, Hugo, Jorge Galindo, Sandra Leon, and Eoin O'Malley. 2016. "State of the Left: Spain, Portugal, Ireland." accessed 14 January 2016. http://www.policynetwork.net/pno.aspx.

Copelovitch, Mark, Jeffry Frieden, and Stefanie Walter. 2016. "The Political Economy of the Euro Crisis." Comparative Political Studies 49 (7):1-30.

De Grauwe, Paul. 2015. "Design failures of the Eurozone." In Secondary Design failures of the Eurozone, ed Richard Baldwin and Francesco Giavazzi. London: CEPR/ VOX. Type of Medium. http://voxeu.org/content/eurozonecrisis-consensus-view-causes-and-few-possible-solutionsAccessed).

De Grauwe, Paul, and Yuemei Ji. 2015. "Correcting for the Eurozone design failures: the role of the ECB." Journal of European Integration 37 (7):739-754.

Dellepiane-Avellaneda, Sebastian, Spyros Blavoukos, Niamh Hardiman, and George Pagoulatos. forthcoming. "Economic Vulnerability in the Eurozone Periphery: 
An Emerging-Market Perspective." Studies in Comparative International Development.

Donovan, Donal. 2016. "The IMF's role in Ireland." Washington DC: IMF, Independent Evaluation Office of the IMF Background Paper, BP/16-02/04. http://www.ieo-imf.org/ieo/files/completedevaluations/EAC_BP_1602_04_The_IMF_s_Role_in_Ireland v5.PDF

Featherstone, Kevin. 2011. " The Greek Sovereign Debt Crisis and EMU: A Failing State in a Skewed Regime." Journal of Common Market Studies 49 (2):193217.

Fleming, Sam. 2017. "Fed told public spending can lift ailing economies." Financial Times, 26 August 2017. https://www.ft.com/content/caa85a3e-8a85-11e79084-d0c17942ba93.

George, A.L., and A. Bennett. 2005. Case Studies and Theory Development in the Social Sciences. Cambridge, MA: MIT Press.

Giannitsis, Tassos, and Stavros Zografakis. 2015. "Greece: Solidarity and Adjustment in Times of Crisis." Berlin: IMK: Macroeconomic Policy Institute, Study 38. https://www.boeckler.de/pdf/p_imk_study_38_2015.pdf

Hallerberg, Mark, and Joshua Bridwell. 2008. "Fiscal Policy Co-ordination and Discipline: The Crisis of the Stability and Growth Pact and Domestic Fiscal Regimes." In The Euro at Ten: Europeanization, Power and Convergence, edited by Kenneth Dyson, 69-86. Oxford: Oxford University Press.

Hardiman, Niamh. 2014. "Repeating History: Fiscal Squeeze in Two Recessions in Ireland." In When the Party's Over: The Politics of Fiscal Squeeze in Perspective, edited by Christopher Hood, David Heald and Rozana Himaz, 139-160. London: The British Academy.

Hardiman, Niamh, Sebastian Dellepiane-Avellaneda, Spyros Blavoukos, and George Pagoulatos. 2017. "Austerity in the European periphery: the Irish experience." In Debating Austerity in Ireland, edited by Emma Heffernan, John McHale and Niamh Moore-Cherry, 78-95. Dublin: Royal Irish Academy.

Hardouvelis, Gikas, and Ioannis Gkionis. 2016. "A decade-long economic crisis: Cyprus versus Greece." Cyprus Economic Policy Review 10 (2):3-40.

IMF. 2012. "The Good, the Bad, and the Ugly: 100 Years of Dealing with Public Debt Overhangs." World Economic Outlook, Washington DC: IMF, World Economic Outlook Report, Chapter 3, pp.101-137. http://www.imf.org/external/pubs/ft/weo/2012/02/pdf/c3.pdf

IMF. 2014. "Greece - Fifth Review under the Extended Arrangement." Washington DC: IMF, IMF Country Report No. 14/151. https://www.imf.org/external/pubs/ft/scr/2014/cr14151.pdf

IMF. 2017. "Greece 2016. Article IV Consultation.", Washington DC: IMF, Country Report No. 17/40. https://www.imf.org/en/Publications/CR/Issues/2017/02/07/Greece-2017Article-IV-Consultation-Press-Release-Staff-Report-and-Statement-by-the$\underline{44630}$ 
IMF Independent Evaluation Office. 2016. "The IMF and the crises in Greece, Ireland, and Portugal: an evaluation by the Independent Evaluation Office." Washington DC: IMF, http://www.ieoimf.org/ieo/files/completedevaluations/EAC_REPORT v5.PDF

Johnston, Alison, and Aidan Regan. 2015. "European Monetary Integration and the Incompatibility of National Varieties of Capitalism." JCMS: Journal of Common Market Studies 54 (2):318-336.

Jones, Erik. 2015. "Getting the story right: how you should choose between different interpretations of the European crisis (and why you should care)." Journal of European Integration 37 (7):817-832.

Jones, Erik, R. Daniel Kelemen, and Sophie Meunier. 2016. "Failing Forward? The Euro Crisis and the Incomplete Nature of European Integration." Comparative Political Studies 49 (7):1010-1034.

Kalaitzake, Manolis. 2017. "The Political Power of Finance: The Institute of International Finance in the Greek Debt Crisis." Politics and Society 45 (3):389-413.

Khan, Mehreen, and Paul McClean. 2017. "Dijsselbloem under fire after saying eurozone countries wasted money on 'alcohol and women'." Financial Times, 21 March 2017. https://www.ft.com/content/2498740e-b911-3dbf-942decce511a351e.

Kickert, Walter, and Tiina Randma-Liiv. 2015. Europe Managing the Crisis: The Politics of Fiscal Consolidation. Abingdon: Routledge.

Kyriakidis, Alexandros. 2016. "The Greek crisis 2009-2015: A comprehensive analysis of the EU-IMF financial assistance programs." International Journal of Employment Studies 24 (2):7-34.

Little, Conor. 2011. "The General Election of 2011 in the Republic of Ireland: All Changed Utterly?" West European Politics 34 (6):1304-1313.

Little, Conor. 2016. "The Irish general election of February 2016: towards a new politics or an early election?" West European Politics 40 (2):479-488.

Marques, Pedro. 2015. "Why did the Portuguese economy stop converging with the OECD? Institutions, politics and innovation." Journal of Economic Geography 15 (5):1009-1031.

Mascherini, Massimiliano, and Stefanie Ledermaier. 2016. "Exploring the diversity of NEETs." Eurofound,

http://www.eurofound.europa.eu/publications/report/2016/labour-marketsocial-policies/exploring-the-diversity-of-neets

Matsaganis, Manos, and Chrysa Leventi. 2014. "The Distributional Impact of Austerity and the Recession in Southern Europe." South European Society and Politics 19 (3):393-412.

Merler, Silvia, and Jean Pisani-Ferry. 2012. "Sudden stops in the euro area." Brussels: Bruegel Institute, Bruegel Policy Contribution, Issue 2012/06, March 2012. http://www.bruegel.org/publications/publication-detail/publication/718sudden-stops-in-the-euro-area/ 
Mody, Ashoka, and Damiano Sandri. 2012. "The eurozone crisis: how banks and sovereigns came to be joined at the hip." Economic Policy 27 (70):199-230.

Moury, Catherine, and André Freire. 2013. "Austerity policies and politics: the case of Portugal." Pole Sud - Revue de Science Politique 39 (2):35-56.

Moury, Catherine, and Adam Standring. 2017. "'Going beyond the Troika': Power and discourse in Portuguese austerity politics." European Journal of Political Research 56 (3):660-679.

Mouzakis, Yiannis. 2017. "Could reforms have prevented Greece's economic collapse?" Macropolis, 1 August 2017. http://www.macropolis.gr/?i=portal.en.the-agora.5904.

Ó Ceallaigh, Daithí. 2017. "Brexit: A Status Report." Dublin: IIEA. http://www.iiea.com/publications/brexit-a-status-report.

OECD. 2015. "Economic Policy Reforms 2015: Going for Growth." Paris: OECD, http://dx.doi.org/10.1787/growth-2015-en

Papaconstantinou, George. 2016. Game Over: The Inside Story of the Greek Crisis. Athens: CreateSpace Independent Publishing Platform.

Porzecanski, Arturo C. 2013. "Behind the Greek Default and Restructuring of 2012." In Sovereign Debt and Debt Restructuring: Legal, Financial and Regulatory Aspects, edited by Eugenio A. Bruno, 33-50. London: Globe Business Publishing.

Público. 2011. "Entrevista à Reuters: Passos Coelho diz que Governo pode ir além das medidas da troika." Público, 6 June 2011. https://www.publico.pt/economia/noticia/passos-coelho-diz-que-governopode-ir-alem-das-medidas-da-troika-1497781.

Regan, Aidan. 2013. "The impact of the eurozone crisis on Irish social partnership: a political economy analysis." Geneva: International Labour Organization, http://www.ilo.org/ifpdial/informationresources/publications/WCMS_213211/lang--en/index.htm?shared_from=shr$\underline{\text { tls }}$

Regan, Aidan. 2017. "The imbalance of capitalisms in the Eurozone: Can the north and south of Europe converge?" Comparative European Politics 15 (6):969990.

Regan, Aidan, and Samuel Brazys. 2017. "Celtic Phoenix or Leprechaun Economics? The Politics of an FDI-led Growth Model in Europe." New Political Economy:1-16.

Sapir, Andre, Guntram B. Wolff, Carlos De Sousa, and Alessio Terzi. 2014. "The Troika and Financial Assistance in the Euro Area: Successes and Failures." Brussels: Bruegel, and the European Parliament, http://www.bruegel.org/publications/publication-detail/publication/815-thetroika-and-financial-assistance-in-the-euro-area-successes-and-failures/

Schmidt, Vivien A. 2010. "The Unfinished Architecture of Europe's Economic Union." Governance 23 (4):555-559.

Schraad-Tischler, Daniel. 2016. "Social Justice in the EU - Index Report 2016. Social Inclusion Monitor Europe." Brussels: Bertelsmann Stiftung, 
http://www.bertelsmannstiftung.de/fileadmin/files/BSt/Publikationen/GrauePublikationen/Studie_NW _Social-Justice-in-the-EU-Index-Report-2015_2015.pdf

Smith, Donal, Mike Fahy, Gavin Murphy, and Brendan O'Connor. 2017. "UK EU Exit: Trade Exposures of Sectors of the Irish Economy in a European Context." Dublin: Department of Finance/ IGEES, http://www.finance.gov.ie/wp-content/uploads/2017/09/170913-UK-EU-ExitTrade-Exposures-of-Sectors-of-the-Irish-Economy-in-a-European.pdf

Terzi, Alessio. 2015. "Reform momentum and its impact on Greek growth." Brussels: Bruegel, Bruegel Policy Contribution Issue 2015/12, July 2015. http://bruegel.org/wp-content/uploads/2015/07/pc_2015_12-.pdf

Theodoropoulou, Sotiria. 2015. "National social and labour market policy reforms in the shadow of EU bail-out conditionality: The cases of Greece and Portugal." Comparative European Politics 13 (1):29-55.

Thorhallsson, Baldur. 2011. "Domestic Buffer Versus External Shelter: Viability of Small States in the New Globalised Economy." European Political Science $10(3): 324-336$.

Torres, Francisco. 2009. "Back to External Pressure: Policy Responses to the Financial Crisis in Portugal." South European Society and Politics 14 (1):5570 .

Véron, Nicolas. 2016. "The IMF's role in the euro area crisis: financial sector aspects." Brussels: Bruegel, Policy Contribution, Issue No.13, 2016. http://bruegel.org/2016/08/the-imfs-role-in-the-euro-area-crisis-financialsector-aspects/

Whelan, Karl. 2012. "ELA, Promissory Notes and All That: The Fiscal Costs of Anglo Irish Bank." Economic and Social Review 43 (4):653-673.

Wise, Peter. 2017. "Portugal's economic revival brings 'crisis of good news' Growth accelerates twice as quickly as eurozone average in first quarter." Financial Times. https://www.ft.com/content/ea7f2a22-4219-11e7-82b6896b95f30f58. 